\title{
Applying the Reader-Response Theory to Literary Texts in EFL-Pre-Service Teachers' Initial Education
}

\author{
Eliana Garzón ${ }^{1}$ \& Harold Castañeda-Peña ${ }^{1}$ \\ ${ }^{1}$ School of Science and Education, Universidad Distrital Francisco José de Caldas, Bogotá, Colombia \\ Correspondence: Eliana Garzón, School of Science and Education, Universidad Distrital Francisco José de \\ Caldas, Carrera 3 No. 26A-40, Bogotá, Colombia. Tel: 571-323-9300 ext. 3038. E-mail: \\ egarzond@udistrital.edu.co
}

$\begin{array}{lc}\text { Received: April 19, } 2015 & \text { Accepted: July 8, } 2015 \quad \text { Online Published: July 28, } 2015 \\ \text { doi:10.5539/elt.v8n8p187 } & \text { URL: http://dx.doi.org/10.5539/elt.v8n8p187 }\end{array}$

\begin{abstract}
This article presents the pedagogical implementation of the reader-response theory in a class of English as a foreign language with language pre-service teachers as they experience the reading of two short stories. The research took place over a 16 week period in which students kept a portfolio of their written responses to the stories. Participants also discussed their interpretations in class. The core constructs of this study are the reader-response theory, the use of literature in English as a foreign language classes and its relation to critical thinking. Results showed that the application of tasks based on the reader-response theory encourages a meaning seeking process as well as the development of higher order thinking skills in future language teachers.
\end{abstract}

Key words: aesthetic reading, efferent reading, EFL literary texts, higher-order thinking skills, reader-response theory, teachers' initial education

\section{Introduction}

English as a foreign language (EFL) teachers could affirm that literature involves a meaningful reading which may have connections with literacy development; however, the old debate surrounding literature in EFL curricula still continues. Therefore, further classroom-based research is needed to clarify the potential roles of literature in the EFL curriculum.

"Literary texts frequently contain social dilemmas and conflicts. Such reading demands personal responses from readers" (Yang, 2002, p. 50). This research-based article presents a pedagogical proposal of reading inspired by the reader-response theory (RRT) for an EFL class of pre-service teachers at university level focused on North American culture (the class being taught by one of the authors). This literary theory recognizes that readers "always bring certain personal, cultural, and literary repertoires to their reading, which need to be explored and compared. In addition, people have one perception when they read a work for the first time, and very different ones, when they reread" (Woodlief \& Cornis-Pope, n.d.). In this re-reading process, readers reconstruct the structure and meaning of ideas expressed by others. They need to do a careful, active, reflective and analytic reading. "Developing a strong interpretation requires being very conscious of all of these processes and changes in reading, understanding individual responses better by comparing them with others, and thus seeing multiple interpretive possibilities" (Woodlief \& Cornis-Pope, n.d.).

Based on RRT, the cultural purpose of this class for EFL pre-service teachers, and considering that after reading a text, many of the participant students demonstrated in their discussions the development of only lower-order thinking skills (Bloom, 1956; Chapman, 2006), the following questions guided this research:

- What types of responses are generated by my students when they are involved in areading process of literary texts based on RRT?

- What thinking skills are developed when students are performing reading based on RRT?

- How doesreader-response reading influence students' performance as readers of literature?

\section{Theoretical Framework and Review of Related Literature}

The content synthesized here illuminated our quest for answers with respect to the questions posed. A definition and characterization of RRT, a historical perspective of the use of literature in teaching languages and its relation 
with EFL education, and the principles of critical thinking through literature are illustrated.

\subsection{Reader-Response Theory: Towards a Definition}

Eagleton (1983) has characterized the history of modern literary theory as occurring in three stages: a romantic "preoccupation with the author", a new critical "exclusive concern with the text", and finally, "a marked shift of attention to the reader over recent years" (p. 74). This is due in large part to the emergence of RRT.

The origins of this theory are in the field of literary criticism from the pioneering work in the 1930s of the literary theorist, Louise Rosenblatt. Rosenblatt's transactional theory of reading places emphasis on the relation between reader and text while constructing meaning. The term transaction, adopted from Dewey's (2008) epistemological writings implies that, during the reading process, the self of the reader and the text are more flexible. Hence, in the RRTthe construction of meaning in the personal literary experience is the main characteristic when thinking of the connection between the reader and the text. According to Connell (1996), "Dewey's epistemological position stresses the transactional character that ties mind and body, subject and object, knower and known" (p. 396). This perspective focuses on the process of knowing, the active role of the knower, and the need for communication among inquirers. Drawing on these epistemological constructs, it can be explained how the RRT is considered as a response to Dewey's position, as it highlights that meaning is constructed based on the reader's aesthetic experience of a text.

Construction of meaning occurs as the reader selects and reflects on his or her own responses. Rosenblatt agrees with Dewey's work on the way that her reading theory does not ignore the way human beings transact with the environment, changing themselves and the conditions simultaneously. As Rosenblatt (1978) states, "what the organism selects out and seeks to organize according to already acquired habits, assumptions, and expectations becomes the environment to which it also responds" (p. 17). Consequently, RRT is significant because it includes the transaction between the reader and the text in the construction of meaning, challenging the tradition in literary theory of privileging text over reader. This however has caused great debate. Connell (2000) points out that "despite the attention now accorded reader response theory among literary theorists, serious debate continues regarding the appropriate use in schools of text-oriented and reader-oriented approaches to the teaching of reading and the study of literature" (p. 29). Nevertheless, it is undeniable that adopting reader-oriented strategies could be pedagogically successful if aesthetic experiences are methodologically incorporated in the curriculum. For Connell (2000), in RRT "the synthesizing process of aesthetic experiences is distinctive from non-aesthetic experiences because it involves 1) an organic immersion in the reader's prior beliefs and experiences; 2) a connection to emotional drives; and 3) a stimulation of imagination" (p. 31). This concurs with Pike's ideas on aesthetic reading in the classroom as it is suggested that "the transaction is one where the shape of the gap or entrance in the text is determined by the shape of the reader who enters as well as the text being entered. Essentially, different readers cause the gap to adopt different shapes. Further, what is indeterminate for one reader may not be indeterminate for another" (p. 63). All this could be interpreted as if the act of reading were constituted by the potentialities offered at a dialogical level by both the text and the reader; it is the complementary relationship between text and reader that (re)constitutes the aesthetic act of reading in a process of synthesis as expressed by both Connell (2000) and Pike (2003). This simply means that the "reader coauthors the literary text" (Justman, 2010, p. 121) or the texts being read, or as claimed by Rosenblatt (1982), this co-authoring process (e.g., the response) "happens when reader meets text" (p. 268).

This in Rosenblatt's (2005a) own words means that "aesthetic reading happens if students have repeatedly found that, in approaching a text called a 'poem' or a 'story,' they can assume that they are free to pay attention to what the words call to consciousness" (p. 37). This implies that the aesthetic act of reading is context driven. Rosenblatt (1982) has also argued in this respect that "in most reading there is not only the stream of choices and syntheses that construct meaning; there is also a stream of accompanying reactions to the very meaning being constructed" (p. 270); these reactions are intertwined with the readers' situated experiences as a reader and as a being in the lifeworld.

Thus, we, as EFL teachers, should encourage students to talk freely about their reading experience with peers and with the teacher so that aesthetic reading can be initiated. According to Rosenblatt (2005b), a reader's interpretation of a text is not a description, but the re-creation the reader makes of the text. Thus, we meet the reader and his or her reading process when an interpretation of a text is supplied. According to Rosenblatt's (1982, p. 271) ideas:

In predominantly efferent reading, the child must learn to focus onextracting thepublic meaning of the text. Attention must be givenmainly to the "token" top-of-the-inner-iceberg, toorganizing the abstract concepts the verbal symbolspoint to. These can yield the information, the directions, the logical conclusions that will be 
theresidue of the reading act. In aesthetic reading, the child must learn todraw on more of the experiential matrix. Insteadof looking outward mainly to the public referents, the reader must include the personal, the qualitative, kinesthetic, sensuous inner resonances of thewords. Hence attention is turned toward "what isimmediately lived-through in transaction with thetext, toward what is being shaped as the story orthe poem".

This indeed lets EFL teachers see that what matters the most is not the referential ideas presented by the text but what students could potentially make out of it. It seems of particular interest to language teachers that both efferent and aesthetic reading should be taught (Rosenblatt, 1982). This particularly could also balance the language teaching of form and meaning-making.

\subsection{Literature: A Historical Perspective of the Use of Literature to Teach Language}

The use of literature might be a strong tool to work with writing in EFL classes. Nevertheless, many literature specialists debate the use of literature in composition classes because they feel that literature "is suited only for the study of literature" (Belcher \& Hirvela, 2000, p. 23). Despite these historical implications, it is remarkable to argue that there is a place for literature in all forms of EFL instruction today. Many benefits can be reaped from using literary pieces in EFL teaching. Literature texts are motivating sources for learning a language because learners become more engaged in the activities proposed in the classroom and can study the language they are learning in a meaningful context. Chien-Lee (2013) states how even from reader-response e-journals to literature, EFL students can be enhanced in a challenging proposal to achieve their learning goals.

Critics against the use of literary texts argue that the language used in literary texts is complex, unnatural and sometimes ungrammatical. However, difficult language and unnatural forms are what students will face in their daily lives and usage of English. Native speakers of English do not speak textbook English or even academic English (Micarelli, 1961). Also, different dialects of English, slang words and idioms are commonly used. Many literary texts and stories present these variations of English.

In reading a literary text, the student is likely to be more engaged in the topic; rather than reading isolated texts presented in English textbooks. This stimulates him/her to be more motivated in the construction of academic essays (Hirvela, 2001). In other words, the literary text motivates the student to think more critically and to write better. As Hirvela (2001) points out, "reading and writing are closely linked as students use writing to explore and make sense of their reading in the course of forming more effective analyses of what they have read" ( $p$. 119). This means that reading literature promotes better reading as well as writing skills. And, contrary to the no literature argument, researchers believe that the study of literary texts can help with the academic texts students will be required to use when they begin their regular studies in their fields of interest.

More importantly is the view of language itself. Many people believe that the purpose of language is "the creation and communication of meaning" (Rigg, 1991, p. 523). Meaning-making is very relevant in reading literary texts. In reading literature, the reader must play an active role in meaning-making. Rosenblatt (1982) has also argued that "words are primarily aspects of sensed, felt, lived-through experiences" (p. 271). So once again, this view of literature as meaning-making helps the reader in both reading between the lines and in compositions in response to the texts. In the meaning-making process it is important to note the background knowledge of the readers. Readers are not blank slates when they read a text (Hirvela, 2001). Instead, they have a lifetime of background experiences and knowledge they bring with them in reading a new text. This background knowledge helps them to analyze and think about the text more, especially when reading a literary text. Therefore, instead of taking on the author's opinion or point of view, they create their own. This act may further enhance the students' reading/writing abilities.

\subsection{Critical Thinking through Literature}

Bloom's taxonomy (1956) includes a six level hierarchy of cognition. In this model, an individual begins with the basic level, which is called knowledge level, and then comprehension level. These lower-order thinking skills require students to define, describe, tell, identify, list, name, explain, discuss, differentiate and restate (Pineda \&Núñez, 2001). The hierarchy of cognition progresses until the thinker reaches the most complex level, which is evaluation. At this level, individuals appraise, assess or critique on the basis of specific standards and criteria. In connection to RRT, it could be argued that "attention is turned toward what is immediately lived-through in transaction with the text, toward what is being shaped as the story or the poem" (Rosenblatt, 1982, p. 271). Individuals move in progressive steps. This means that one needs to master a given process before proceeding to the next. This does not imply that each step acts in isolation or that thinking is composed of fragments. Thus, human learning entails a cyclical activity in which we constantly attach our beliefs and personal values to our knowledge to elaborate more sophisticated thinking processes (Pineda, 2003). In this respect, it is also important to consider Rosenblatt's (1982) perspective as she argued that "aesthetic reading [...] is not efferent reading with 
a layer of affective associations added on later. (I [Rosenblatt herself] call this the "jam on bread" theory of literature.) Rather, we have seen that the aesthetic stance, in shaping what is understood, produces a meaning in which cognitive and affective, referential and emotive, denotational and connotational, are intermingled" (p. 273). That meaning-making process, we would like to argue, embraces processes of critical thinking. The question that arises is related to the methodological procedures a language teacher could implement to heighten an aesthetic experience which is by nature critical and should be associated with the higher levels of thinking very wellknown in the literature (e.g., Bloom's Taxonomy (Bloom, 1956)). Schmidt (2002, p. 106) considers that a number of questions we might ask about literary texts is based on the variations of six basic questions. These basic questions provide a paradigm for the construction of more specific questions about particular texts, and they are most likely to appear in the following order:

- What is ? (knowledge)
- What is ${ }_{\text {about? (comprehension) }}$ connected/related to? (application)
- What are the significant components of
- What does_ mean? (synthesis)
? (evaluation)

Each of these six basic questions relates to a category of the classic Bloom's (1956) taxonomy of cognitive levels, and so his list of these levels is an invaluable resource for teachers as they construct questions. According to Schmidt (2002), there are two obvious benefits to following this scheme: "(1) it ensures the best possible scaffolding of new and complex ideas, and (2) it models good critical thinking for any inquiry that these students will undertake in their respective futures" (p. 119). In an effort to connect this to Rosenblatt's $(1965,1978)$ seminal work, it could also be argued that these sets of questions or variations of them could propel the readers' imagination evoking the needed experiences that precede the potential readers' responses: "imagination is needed also in cognitive processes, in the process of remembering, in thinking of the past, in thinking of alternative solutions to a problem" (Rosenblatt, 1982, p. 273).

\subsection{Connections between Theory and Literature Reading}

What needs to be remarked at this point is how the connection between literature reading and RRT was done. Delahoyde (2011) states that reader response criticism places emphasis on knowing how the reader can join the author of a text to construct meaning, and in this specific study, how the members of the group or the community of readers can learn from North American culture through their experience of reading literature and sharing interpretation with others.

Educating student-teachers of English and designing English curricula for them must bear in mind who they are and where they are headed. Consequently, the approach to reading literature is a path to enhance student-teachers of English in the understanding of the language as a whole and as the direct contact with their lives and the world. Rosenblatt (1985) argues that the teacher's influence should respect the authentic nature of literature itself. However, it should be clarified that RRT was not conceived of as a language learning approach originally but it has been adapted and adopted by researchers who belong to this applied linguistics domain (see the works by Carlisle, 2000; Davis, 1989; Hirvela, 1996, 2001; Liaw, 2001). Sheridan (1991) notes that in a reader-response classroom, the proper subject of writing is the experience of reading itself. He argues that students will benefit most when their writing helps them become better readers. Furthermore, he stresses the importance of writing that requires students to reread literary texts, a point also mentioned by Jenkins and Moses (1992). According to Yilmaz (2012), "both literature and language can serve as the complement to each other, which is conducive to the development of language skills" (p. 86). Thus, it seems that in the RRT frameworkthe literary experience, in the EFL classroom, should become an encounter between the reader and the text, rather than a strategy or technique to study history, philosophy, biography, literary genres or grammar.

Although the literary experience of reading may involve those aspects of learning, the immediate relationship with the reader is the transaction he or she has with the text. From this moment, our pedagogical implementations, as EFL teachers, should begin in assisting our student-teachers in studying that transaction rather than focusing on other issues. This has also been recognized in the literature as the personal-response approach (Rashid, Vethamani, \& Rahman, 2010) which has a position as a model for the teaching of literature. For example, Khatib, Rezaei and Derakhshan (2011) in their review identify different authors which position reader-response as an epistemological approach to knowledge generation in literature teaching, based on the interaction between reader and text as this could be seen as a defined type of encounter, and these authors also 
examine different applications of such interaction in EFL/ESL teaching. Amer (2003) goes on to clarify the epistemological status of the reader-response approach (as this author appears to call Rosenblatt's RRT proposal) placing it within the realm of constructivism where "from a pedagogic perspective, 'multiple interpretations' allow for creative and critical thinking to take place in an atmosphere where there are no threats nor any compulsion to learn for the 'correct' answer or to compete for the 'best' interpretation" (p. 68). Literary reading must not be reduced to a grammar exercise to learn linguistic aspects of English, but must be understood as an aesthetic work that allows readers to feel, see and think. Into the context of that reader-response, other tasks and themes may be introduced, but the influence inherent in the literary text must be respected. Therefore, RRT is not based on arbitrary or senseless comments from the reader; instead, it is focused on finding meaning in the act of reading literature itself and exploring the ways individual readers and a community of readers experience the world and culture immersed in the literary text. According to Govindarajoo and Mukundan's (2013) study of the Malaysian context "Reader-response theory [...] sees the reader as an active participant who produces a unique reading experience because he brings into the reading experience his own physical and psychological conditions causing his personal history to become entrenched into the creation and interpretation of the text" (p. 79). This is the understanding adopted in this research paper in the context of initial language-teacher education where there is apparently little research within the RRT framework as part of pre-service teachers' knowledge.

\section{The Study}

This research was conducted in one advanced EFL class of the Modern Language Programme at a public university in 2009 where future English-language teachers are educated. The holistic training of research teachers in Spanish and English for basic and middle education in Colombia is one of the pillars of the Modern Language Programme, which has 10 semesters of study. Its major areas are English (foreign language) and Spanish (mother tongue). English-language classes in this programme are taught for seven consecutive semesters.

\subsection{Participants}

Although the entire class, comprised of 19 students, aged 18 to 25 , was observed, surveyed, video-recorded, and asked to fulfil the same requirements, only seven participants were selected. According to Patton (1990) and what he states as purposive sampling, this small group was chosen because of certain criteria. All of them followed the whole writing process, attended all the discussions, and willingly handed in their portfolios at the end of the semester to gather and analyze data.

\subsection{Data Collection Instruments, Techniques and Procedures}

Elements of the grounded approach to analyze qualitative datawere necessary to focus on how the themes and patterns surfaced from the raw data as it was read (Corbin \& Strauss, 2008). The entire data collection process was as follows: first, the students' reading backgroundswere compiled through a questionnaire. This questionnaire included open and closed questions related to students' experiences with literature reading in L1 and EFL. Second, students wrote their reflections after reading the literary texts and collected them in a portfolio. In addition, students were engaged in classroom discussions after reading the literary texts. In these discussions, they were first organized in small groups to share their interpretations of the stories read, and then they shared their interpretations with the whole class. As each reader interprets differently, there were diverse responses and the discussion of the main topics discovered in the stories became enriching.

Finally, a research interview was applied to validate all the information collected (Kvale \& Brinkmann, 2008). This interview was used not only to confirm information provided in the initial questionnaire, the written reflections and the discussions, but also to understand the significance of this reading proposal for students and to delve into those aspects that needed further research. This interview was audio-recorded.

\subsection{Pedagogical Intervention}

As the general objective of the class in which this research was carried out was the study of North American culture, literature was the source to do this. Therefore, two stories written by Ray Bradbury were selected to work on a critical process of reading based on RRT, during 16 weeks of the academic semester: The Jar and The Emissary. The former because it has themes such as life in Louisiana, black people, farm people, religiousdiversity in the USA, carnival and personal identity. The latter was selected because it is closely related to ghosts, cemeteries, death and life after death. The selection criteria of these stories were based on the needs analysis conducted at the beginning of this study, where horror, mystery and fantasy were the literary topics students demonstrated being interested in reading. Although Edgar Allan Poe is the master of horror, Ray Bradbury was chosen as a contemporary author follower of Poe, because he was not known to the group of 
participants and the stories were authentic literary texts.

These readings followed certain stages to guide students in the reading process of interacting with the text itself. These stages were: pre-reading, first reading, re-readings and critical reading. Here, it is important to remark that in the first readingsthe students were asked to venture into the efferent reading process. In this process, students completed assignments which focused on conventional literary elements such as characters, plot and setting. However, the final readingsdemanded that the students continue to develop and build their interpretation of the text's meaning.

As the research questions of this study are aimed at knowing the type of responses my students generated according to the principles of RRT and also their thinking skills when reading, all the responses they provided when reading the two stories were organizedin a portfolio. My hope was that the portfolio would increase the students' understanding of their own reading process and thus enable them through writing to grow more confident about their reading (Chien-Lee, 2013). Discussions in class were also developed; first, in small groups, and then, with the whole class. These discussions were based on students' individual interpretations of the two stories they read. When discussing with their peers, they started to construct meaning as a community of readers.

\section{Data Analysis and Findings}

The research questions addressed the issues of students' responses, thinking skills and their performance as readers of literature. The type of data gathered through the research process was qualitative and the unit of analysis was students' responses to the two literary stories. I used their written and oral responses to start organizing and naming the categories and subcategories of this study. Written responses included personal narratives, connections between personal experiences and the stories, and reviews of the story. Basically, written responses were focused on interpretation of the texts. On the other hand, oral responses were captured while students were engaged in group discussions and included responses to peers' questions, personal interpretations of the text, analytical comments, and stepping into the stories.

The data were colour coded when reading and re-reading students' written productions and the video and audio transcriptions, looking for recurrent patterns and establishing relationships among them (Freeman, 1998). Then, I reviewed those patterns and grouped the themes. I identified seven broad categories and five subcategories (see Table 1)including those aspects that did not fit the group's emerging structures of analysis; that is, the outliers (Freeman, 1998).

Table 1. Categories resultingfrom the analysis

\begin{tabular}{|c|c|c|}
\hline Research Questions & Categories & Subcategories \\
\hline \multirow[b]{3}{*}{$\begin{array}{l}\text { What types of responses are generated } \\
\text { by my students when they are involved } \\
\text { in a reading process of literary texts } \\
\text { based on RRT? }\end{array}$} & Affective responses & \multirow{7}{*}{$\begin{array}{ll}\text { - } & \text { Personal experiences } \\
\text { - } & \text { Literary background } \\
\text { - } & \text { Other works } \\
\text { - } & \text { Personal beliefs } \\
\text { - } & \text { Literature and reading process }\end{array}$} \\
\hline & Queries & \\
\hline & Associative responses & \\
\hline \multirow[t]{3}{*}{$\begin{array}{l}\text { What thinking skills are developed } \\
\text { when performing reading based on } \\
\text { RRT? }\end{array}$} & Reflective responses & \\
\hline & Interpretive responses & \\
\hline & Inferential responses & \\
\hline $\begin{array}{l}\text { How does the reader-response type of } \\
\text { reading influence students' performance } \\
\text { as readers of literature? }\end{array}$ & $\begin{array}{l}\text { Different worlds, different } \\
\text { perceptions }\end{array}$ & \\
\hline
\end{tabular}

Source: Own.

In answer to what type of responses our students generated when they were involved in a reading process of literary texts based on RRT, the data gathered and analyzed displayed affective responses, queries, associative responses, reflective responses, interpretive responses and inferential responses. Affective responses, for example, account forstudents' responses that express feelings towards the stories read or their own reading 
process. The following excerpts evidence these feelings:

I want to say that I love literature because it permits us to identify the world and the reality where we are. So it permits us to build the identity that has gone losing little by little. A modern world is affected our mind and each one of us, is a copy of others. I think that we are free in literature. Besides, it permits us to have a critical point of view of the reality.

(S7 (S = Student), Paper 10, [sic])

For that reason the story was entertaining because I had to discover what happened with the jar, besides getting to know the truth about the jar's contents.

(S5, Paper 1, [sic])

With these responses, students expressa type of affective attachment to the texts read in class and evaluative ideas regarding literature. These ideas about literature may perhaps be transferred into their future practice as language teachers, but what seems important to be highlighted in this data set is that criticality arises when these readers step away from efferent moments and embrace aesthetic ones. This could be valuable as part of language teacher education.

In the category of queries, all the questions that emerged when students read the stories were included. Some queries indicated a lack of understanding of some parts of the stories and some others were stated to clarify meaning in the text. Some students brought up questions to be answered in the discussions, some others included questions as a way of guiding themselves in the construction of meaning.

115) S1: But I have a question about the last part of the story...remember that Dog was very

116) late and he arrived with a visitor and Dog smelled to cemeteryyyy...ground? (laughs) I don’t

117) know, so don't you think that the visitor who arrived with Dog is the teacher?

118) S2: I think so, or death...

119) S3: Or maybe it's the teacher's soul and it's going to take him with her (laughs).

(Class discussion [sic], video transcription, The Emissary)

These questions were formed after the first reading, so they were answered after further readings of the stories or after the discussions in class. Wilson (1989) gives further credence to the students' ability: "When students read to answer their own questions, they read with attention, often noticing words or images we might never have thought to point out" (p. 65). Students also made relevant elements related to aspects of language learning (e.g., the pronunciation of cemetery) which could be important for them as language analysts who will be language teachers in the future. Notice how in line 116, S1 also wants to rectify her lack of knowledge of the appropriate word for graveyard odour.

Associative responses include these reminiscences relatedto the reading. In these responses, it could be identified that future language teachers brought personal memories, comparisons with other works similar to the stories being read, or identified people with characters in the story. Therefore, three subcategories were found here: personal experiences, literary background, and other works. The next excerpt makes this category evident:

58) S6: Because ehhmmm, when I was 15 years old, in those days my grandmother died, yes?

59) And I used to, to sleep in the same room, and ehhh, when she died ehhhmmm I, I continue

60 ) sleeping there, but I wasnot alone, I, I was with my aunt and one cousin.

61) T: Yeah.

62) S6: And one day, one night, I, I couldn't sleep and I look, look, look...looked

63) T: /lukt/

64) S6: /lukt/ a shadow that ehhh, enter...into the room and ehhh, disappeared ehhmmm,

65) among them, yes? In this space was the bed of my grandmother, yes? And...ehhh,

66) immediately the lights...turn on and I, I wake up, wake my aunt up and...together we went

67) out, yes?And nobody was...

68) T: Nobody was there.

(S6, Interview, [sic]) 
Making associations give students an opportunity to show their own experience of life and to find a real connection between the text and the reality around them. In the case of S6, she narrates something relevant from a personal experience about a possible ghost in her bedroom, associated with her late grandmother, as that bedroom had been shared with other family members including the dead grandparent. The ghost story associated as a response to reading The Jar cannot be labelled as correct or incorrect. This is a text derived from S6's aesthetic act of reading that could demonstrate how S6 assesses a situation she went through as a subjective experience. What also appears to be important here is to understand that S6 was exercising critical thinking instances where she is able to rely on beliefs about ghosts to judge and explain why a witnessed lifeworldevent occurred. This makes us think of how culturally situated responses to readings are and this is another aspect to be taken into account in RRT instruction. In terms of initial teacher preparation this also indicates that S6 is acquiring the skills to narrate her personal experiences from a critical perspective as a response to reading. According to Rosenblatt (1965),

The reader brings to the work personality traits, memories of past events, present needs and preoccupations, a particular mood of the moment, and a particular physical condition. These and many other elements in a never-to-be duplicated combination determined his response to the peculiar contribution of the text (p.31).

These students' responses that reflect on their own experiences, attitudes or observations in relation to the ideas of the text and their reading process are part of the category of reflective responses. Two subcategories were identified here according to the type of reflections made by the students. These subcategories were personal beliefs and literature and reading process. Thus, we have included not only these generalized statements about life elicited by the reading of the stories, but also those statements which put certain aspects of the stories into a larger context. According to Tompkins (1980), each reader brings different experiences of life to the text. The text has meaning within the reader. Thus, readers will recreate diverse interpretations and responses based on prior beliefs and attitudes (e.g., S6 above). They will reflect on what is stated in the text as well as on their own process as readers of literature.

I think the jar reflects the farmers' thoughts, in general, not only in USA, also in South America, when people don't have an educational training, they can believe in anything that seems powerful and strange. Power has been a main objective for people, and Charlie chose power instead of his wife, each one decided to face this situation according to their feeling and not according to the real situation.

(S1, Paper 7, [sic])

I think that the dreams and the wishes are the motor of the world without them the things made by the man would not be a reality, most of the things are made by the result of human being imagination and the creativity to make a better world through ideas and thoughts.

\section{(S5, Paper 4, [sic])}

It is remarkable how S1 extends the scope of his interpretation to what could be assumed as a contemporary situation of farmers in South America from his own point of view. This is also an expression of how the reader understands actions within specific social conditions as could partly also be the case of S5's response. We would like to argue that S1 and S5 display traces of critical thinking in their responses. Both students seem not only to be enacting an aesthetic reading process but they are also incorporating higher thinking skills in this process as they evaluate social situations based on their reading experiences and apparently on their personal background knowledge.

Furthermore, those responses that represent students' attempts to interpret the meanings of the stories based on the events of the story are grouped into the category of interpretive responses. Students make statements as to their opinions of actions in the stories, and then back them up with quotations or examples from the reading. In other words, interpretive responses deal with students' attempts to make meaning of the stories based on what was explicitly stated in the text. For example:

On the other hand by its description, the town seems to be a boring, poor, small, and mysterious place, where everyone knows the life of everybody. Where people are involved in a routine situation day after day, so the days look like the same.

\section{(S2, Paper 3, [sic])}

Finally, inferential responses were the last category found in the data to answer the main research question. These responses are those which attempt to see not only content but multiple layers of meaning in the stories. 
Other idea or theme hidden in The Emissary is about solitude. In the case of Martin he only had two very close friends Dog and his teacher and when she died it generated a deep feeling of sadness in Martin and later when Dog disappeared it was worst because the unique being who maintained him communicate with the world outside was Dog, his other half part of life, for Martin, his life without Dog was not life, although Martin was with his parents he needed the company of his best and unique friend, situation that in the real life many people experiment or live every day.

(S4, Paper 12, [sic])

They attempted to locate and explain symbolism and allegory, for instance, statements of theme and meaning are included in inferential responses. These responses deal with the students' attempts to make meaning of the story based on what was implicit.

To answer the related questionabout how reader-response reading influences students' performance as readers of literature, we analyzed the reflections of these future language teachers on their own reading process. Here, the category Different Worlds, Different Perceptionswas constructed. Students' experiences with literature in previous semesters and those throughout the process of this semester emerged when analyzingthe data. Moreover, the strengths and weaknesses students found in their process of reading the two stories were taken into account. The following excerpt shows the feelings and reflections of a student as a reader of literature after following the process of reading under RRT. S2 finds she is able to read between the lines (an expression of aesthetic reading along with critical thinking) and makes this conscious at theinterview referring also to her abilities to analyze literary texts. Additionally, it is possible to trace a sense of achievement as a critical reader.

66) OK I, I feel that I mmm I really I have really improved in my critical reading process,

67) not only in Spanish but also in English, because I have associated the knowledge acquired

68) in one[clearing throat], in one subject ahhh, with the other and [clearing throat] it had been

69) really interesting for me because I can at this moment I can find ina text the perception of

70) the author discover how is the, how the social and political or economic environment is,

71) ehhh I can understand why the why or what is the... issue behind hiding behind lines and I

72) can establish a connection between my experiences, my previous knowledge with the new

73) one and the most interesting that I can find in the text that my reality is reflected there

74) and myself, my own experiences, and but in involved in annnn in a dark or in anatmosphere

75 ) in which thee a mysterious tone or note establish ehh establish a connection between the

76) characters and you really can find ehhhhh, what you want to find, the reality represented

77) in the text but with aaa a tone of myster...mystery and darkness.

(S2, Interview, [sic])

The findings classified in the previous categories and subcategories illustrate the most recurrent issues in relation to the types of responses generated by the pre-service language teachers when they were involved in a reading process based on RRT. We simply used a few cases to substantiate our claims but there are more examples in the data set which cannot be listed here. Concerning the question about the thinking skills developed when students are performing reading based on RRT, it could be considered that at every stage of the reading process the students developed higher reading strategies and thinking skills. When students were asked to answer questions about specific situations in the stories or features of the characters, a knowledge skill of the stories was being developed. Then, when students became more familiar with the basic language of the stories, they could move to a second level of comprehension. Here, they evidenced their understanding of the story by comparing, interpreting, giving descriptions, and stating main ideas. After this level, they moved to a level of application, where they tried to solve problems by using the knowledge they had about the story. In the next stage, students had reached the analysis level because they analyzed, compared, and even inferred facts from the stories. At the end of the stages of rereading, students could evaluate what they read. During this enriching experience of reading, students' principal concern was to interpret and infer about literature pieces.

\section{Conclusions and Pedagogical Implications}

Having students assume new perspectives in a story they have already read, made them aware that there are no exact interpretations in the text. Students also became more confident when giving their opinions about the reading and showed more interest when listening to others' interpretations. RRT made literature reading more 
meaningful and real for students. They became personally involved in the reading process because they brought all their life experiences. When students came to realize that their own lives and their own personal thinking were important, a new appreciation for the reading experience of literature appeared to be born.

RRT also enables the design of activities that guide students to think critically about what they read. This theory makes students go beyond the literal levels of reading. Students were interpreting, enjoying and inferring about literature while involved in this reading process. The stories they read gave them the opportunity to talk about their own insights, helping them to speak English in front of their classmates as part of their initial education as future language teachers. This thoughtful process of reading seems to lead to critical thinking. Therefore, when students read literature, they interact with the text. By interacting with the text, they interpret what they read. By interpreting what they read, they can work towards speaking English more creatively. Consequently, they could become more aware of how to work with literature in EFL when they become in-service teachers.

Including literature in language classrooms where future language teachers are educated aims to develop critical thinking skills, adds to the students' personal growth and their autonomy both as language learners and as individuals, and contributes to their ability to empathize and comprehend others' values and needs. Literature should indeed have a place in the EFL classroom because it provides a key to motivating students to read in English and it is an ideal vehicle for illustrating language use and for introducing cultural assumptions.

RRT allows students to explore literary texts from their personal experience, learning about themselves and those around them as they discover and develop their interpretation about the meaning of the text. Only after they have had the opportunity to make the meaning of the text their own, can they begin to move from the aesthetic experience to the efferent, according to what Rosenblatt (1965) affirms.

In short, the conclusions suggest ways to rethink the teaching of EFL and the role of literature in EFL classrooms for pre-service teachers. This does not mean that changes are not already taking place. Instead, this work and the ideas presented here are reflective of the changing knowledge within this field of study and its contribution to the continual quest for improvement in education. Consequently, integrating literature into the curriculum while applying RRT will help EFL-pre-service teachers to become critical human beings, since this implies teaching more than the basic communicative skills necessary for getting by in the target language.

\section{References}

Amer, A. A. (2003). Teaching EFL/ESL literature. The Reading Matrix, 3(2), 63-73.

Belcher, D., \& Hirvela, A. (2000). Literature and L2 composition: Revisiting the debate. Journal of Second Language Writing, 9(1), 21-39. http://dx.doi.org/10.1016/S1060-3743(99)00021-1

Bloom, B. S. (1956). Taxonomy of educational objectives: The classification of educational goals: Handbook I, Cognitive domain. New York, NY: McKay.

Carlisle, A. (2000). Reading logs: An application of reader-response theory in ELT. ELT Journal, 54(1), 12-19. http://dx.doi.org/10.1093/elt/54.1.12

Chapman, A. (2006). Bloom's taxonomy of learning domains. Retrieved April 3, 2015, from http://www. businessballs.com/bloomstaxonomyoflearningdomains.htm

Chien-Lee, H. (2013). The reader response e-journal: An alternative way to engage low achieving EFL students. Language Teaching Research, 17(1), 111-131. http://dx.doi.org/10.1177/1362168812457539

Connell, J. (1996). Assessing the influence of Dewey's epistemology on Rosenblatt's Reader Response Theory. Educational Theory, 46(4), 395-413. http://dx.doi.org/10.1111/j.1741-5446.1996.00395.x

Connell, J. (2000). Aesthetic experiences in the school curriculum: Assessing the value of Rosenblatt's Transactional Theory. Journal of Aesthetic Education, 34(1), 27-35. http://dx.doi.org/10.2307/3333652

Corbin, J., \& Strauss, A. (2008). Basics of qualitative research. Thousand Oaks, CA: Sage Publications.

Davis, J. (1989). The act of reading in the foreign language: Pedagogical implications of Iser's reader-response theory. The Modern Language Journal, 73(4), 420-428. http://dx.doi.org/10.1111/j.1540-4781.1989.tb05323.x

Delahoyde, M. (2011, January 6). Reader-response criticism. Introduction to Literature. Retrieved from http://public.wsu.edu/ delahoyd/reader.crit.html

Dewey, J. (2008). In J. Boydston (Ed.), Thelater works of John Dewey: Miscellaneous writings (The collected works of John Dewey, 1882-1953) (Vol. 17, pp. 3-48). Carbondale, IL: Southern Illinois University Press.

Eagleton, T. (1983). Literary theory: An introduction. Oxford, UK: Basil Blackwell Publishers Limited. 
Freeman, D. (1998). Doingteacher research: From inquiry to understanding. Boston, MA: Heinle and Heinle.

Govindarajoo, M., \& Mukundan, J. (2013). Young adult literature in the Malaysiansecondary school. English Language Teaching, 6(11), 77-88. http://dx.doi.org/10.5539/elt.v6n11p77

Hirvela, A. (1996). Reader-response theory and ELT. ELT Journal, 50(2), 127-134. http://dx.doi.org/10.1093/elt/50.2.127

Hirvela, A. (2001). Connecting reading and writing through literature. In D. Belcher, \& A. Hirvela (Eds.), Linking literacies: Perspectives on L2 reading-writing connections (pp. 109-134). Ann Arbor, MI: The University of Michigan Press.

Jenkins, R., \& Moses, J. (1992). The uses of chaos, the making of meaning: Portfolio assessment in literature classrooms. New Directions in Portfolio Assessment Conference. Oxford, OH: Miami University.

Justman, S. (2010). Bibliotherapy: Literature as exploration reconsidered. Academic Questions, 23, 125-135. http://dx.doi.org/10.1007/s12129-009-9147-1

Khatib, M., Rezaei, S., \& Derakhshan, A. (2011). Literature in EFL/ESL classroom. English Language Teaching, 4(1), 201-208. http://dx.doi.org/10.5539/elt.v4n1p201

Kvale, S., \& Brinkmann, S. (2008). InterViews: Learning the craft of qualitative research interviewing. Thousand Oaks, CA: Sage Publications.

Liaw, M. L. (2001). Exploring literary responses in an EFL classroom. Foreign Language Annals, 34(1), 35-44. http://dx.doi.org/10.1111/j.1944-9720.2001.tb02800.x

Micarelli, C. N. (1961). Aims in foreign language study. The Modern Language Journal, 45, 296. http//dx.doi.org/10.1111/j.1540-4781.1961.tb04440.x

Patton, M. Q. (1990). Qualitative evaluation and research methods (2nd ed.). Newbury Park, CA: Sage Publications.

Pike, M. (2003). From personal to social transaction: A model of aesthetic reading in the classroom. Journal of Aesthetic Education, 37(2), 61-72. http://dx.doi.org/10.2307/3527455

Pineda, C. (2003). Searching for improved EFL classroom environments: The role of critical thinking-related tasks. Bogotá, Colombia: Publicaciones Universidad Externado de Colombia.

Pineda, C., \& Núñez, A. (2001). Getting in touch with reality: An English curriculum to boost students' critical thinking skills and interest in global issues. HOW, A Colombian Journal for English Teachers, 9, 34-39.

Rashid, R., Vethamani, M., \& Rahman, S. (2010). Approaches employed by teachers in teaching literature to less proficient students in form 1 and form 2. English Language Teaching, 3(4), 87-99. http://dx.doi.org/10.5539/elt.v3n4p87

Rigg, P. (1991). Whole language in TESOL. TESOL Quarterly, 25(3), 521-543. http://dx.doi.org/10.2307/3586982

Rosenblatt, L. M. (1965). Literature as exploration. New York, NY: The Modern Language Association.

Rosenblatt, L. M. (1978). The reader, the text, the poem: The transactional theory of the literary work. Carbondale, IL: Southern Illinois University Press.

Rosenblatt, L. M. (1982). The literary transaction: Evocation and response. Theory into Practice, 21(4), 268-277. http://dx.doi.org/10.1080/00405848209543018

Rosenblatt, L. M. (1985). Language, literature, and values. In S. N. Tchudi (Ed.), Language, Schooling, and Society. Upper Montclair, NJ: Boynton.

Rosenblatt, L. M. (2005a). Literature: S.O.S.! Voices from the Middle, 12, 34-38.

Rosenblatt, L. M. (2005b). From 'What facts does this poem teach you?' Voices from the Middle, 12, 43-46.

Schmidt, J. (2002). Practicing critical thinking through inquiry into literature. In J. Holden, \& J. Schmidt (Eds.), Inquiry and the literary text: Constructing discussions in the English classroom (Vol. 32, pp. 104-112). Classroom Practices in Teaching English Series, National Council of Teachers of English.

Sheridan, D. (1991). Changing business as usual: Reader response in the classroom. College English, 53, 804-814. http://dx.doi.org/10.2307/377823

Tompkins, J. (1980). The reader in history: The changing shape of literary response. In J. P. Tompkins (Ed.), 
Reader Response Criticism. Baltimore, MD: Johns Hopkins University Press.

Wilson, N. (1989). Learning from confusion: Questions and change in reading logs. English Journal, 62-68. http://dx.doi.org/10.2307/817960

Woodlief, A., \& Cornis-Pope, M. (s.f.). On the reading process: Notes on critical literary philosophy and pedagogical practice. Retrieved from http://www.vcu.edu/engweb/theory.html

Yang, A. (2002). Science fiction in the EFL class. Language, culture and curriculum, 15(1), 50-60. http//dx.doi.org/10.1080/07908310208666632

Yilmaz, C. (2012). Introducing literature to an EFL classroom: Teacher's instructionalmethods and students' attitudes toward the study of literature. English Language Teaching, 5(1), 86-99. http://dx.doi.org/10.5539/elt.v5n1p86

\section{Copyrights}

Copyright for this article is retained by the author(s), with first publication rights granted to the journal.

This is an open-access article distributed under the terms and conditions of the Creative Commons Attribution license (http://creativecommons.org/licenses/by/3.0/). 